\title{
Characterization of cobalt-copper antagonism in the study of copper-stimulated growth in weanling pigs
}

\author{
E.T. Kornegay*, W. Zhou, J.W.G.M. Swinkels and C.R. Risley
}

Department of Animal and Poultry Sciences, Virginia

Polytechnic Institute and State University,

Blacksburg, Virginia 24061-0306, USA

(Received 28 December 1994; accepted 16 February 1995)

\begin{abstract}
Two experiments with 96 crossbred pigs each were conducted to study the effectiveness of Co to reduce tissue $\mathrm{Cu}$ accumulation in pigs. A $2 \times 3$ factorial arrangement of treatments, two levels of $\mathrm{Cu}$ (15 and $280 \mathrm{mg} / \mathrm{kg}$ ) and three levels of added Co $(0,150$ and $300 \mathrm{mg} / \mathrm{kg}$ ), was used in both cxperiments. The initial body weight was $8.2 \mathrm{~kg}$ in experiment 1 and $7.2 \mathrm{~kg}$ in experiment 2 . Tissue samples were taken at $\mathrm{d} 35$ of experiment $\mathrm{I}$ and $\mathrm{d} 14$ and $\mathrm{d} 28$ of experiment 2 for mineral analysis. Cobalt failed to alleviate $\mathrm{Cu}$ deposition in the liver and brain at both dietary $\mathrm{Cu}$ levels and increased $(\mathrm{P} \leqslant 0.05) \mathrm{Cu}$ deposition in the liver of the $150 \mathrm{mg} / \mathrm{kg}$ Co group. In contrast, increasing dietary Co linearly decreased $(\mathrm{P} \leqslant 0.05) \mathrm{Cu}$ deposition in the kidney and $\mathrm{Zn}$ deposition in the liver. High dictary $\mathrm{Cu}$ increased $(\mathrm{P} \leqslant 0.05)$ serum $\mathrm{Cu}$ concentration and $\mathrm{Cu}$ deposition in the liver, brain and kidney. Copper feeding stimulated $(\mathrm{P} \leqslant 0.05)$ growth only during the first week in experiment 1 . Dietary supplementation of 150 and $300 \mathrm{mg} / \mathrm{kg}$ of Co greatly depressed $(P \leqslant 0.05)$ feed consumption and reduced growth rate $(\mathrm{P} \leqslant 0.05)$. In summary, the $\mathrm{Cu}-\mathrm{Co}$ antagonism is tissue specific and could not be used to prevent liver or brain $\mathrm{Cu}$ accumulation. In addition, the Co tolerance level for weanling pigs is lower than $150 \mathrm{mg} / \mathrm{kg}$.
\end{abstract}

KEY WORDS: copper, cobalt, pigs

\section{INTRODUCTION}

Although dietary supplementation of high levels of $\mathrm{Cu}$ is a common practice in the United States swine industry (Ewan, 1986), the mechanism for $\mathrm{Cu}$-stimulated growth is not well understood (Bowland, 1991). Pigs fed high

\footnotetext{
* Corresponding author
} 
levels of $\mathrm{Cu}$ in the diet develop excessive $\mathrm{Cu}$ deposits in their liver, kidney and other organs (Cromwell et al., 1989; Kornegay et al., 1989), and it is important to understand whether this $\mathrm{Cu}$ deposition is necessary for $\mathrm{Cu}$-stimulated growth. An efficient method of removing $\mathrm{Cu}$ deposited in tissues is needed to study $\mathrm{Cu}$-stimulated growth.

Sulphide, in the form of ferrous sulphide or sodium sulphide, has been shown to be an effective agent to prevent $\mathrm{Cu}$ deposition in the liver of pigs fed high $\mathrm{Cu}$ diets (Cromwell et al., 1978; Prince et al., 1979; Ridberiro de Lima et al., 1981). Sulphide, however, could not reduce $\mathrm{Cu}$ deposition in the kidney, which suggests that the Cu-sulphide antagonism is tissue specific. It has been reported that injections of inorganic Co greatly enhanced rat urinary Cu excretion (Rosenberg and Kappas, 1989a, b) and reduced the deposition of $\mathrm{Cu}$ in the kidney and liver (Rosenberg and Kappas, 1989b). Copper excretion induced by Co was reported to have no accompanying urinary loss of $\mathrm{Zn}$, which is typical of other $\mathrm{Cu}$ removing agents (Rosenberg and Kappas, 1989b; Walshe, 1956). Therefore, it seems that inorganic $\mathrm{Co}$ could prevent tissue accumulation of $\mathrm{Cu}$ by enhancing $\mathrm{Cu}$ excretion and thus could be a potential tool for studying the importance of $\mathrm{Cu}$ deposition in $\mathrm{Cu}$-stimulated growth.

Very little is known about the effect of Co on pigs. An organic form of Co, vitamin $B_{12}$, is known to be an essential nutrient for pigs (NRC, 1988). Inorganic Co per se is not considered to be essential for pigs (Underwood, 1971). In studying the toxicity of Co in pigs, Huck and Clawson (1976) examined the interaction between dietary $\mathrm{Co}, \mathrm{Mn}, \mathrm{Fe}$ and $\mathrm{Zn}$. They reported that a corn-soyabean diet containing $200 \mathrm{mg} / \mathrm{kg}$ of Co did not produce adverse effects. However, antagonistic relationships were found between $\mathrm{Co}$ and the three other minerals studied, but their study did not address the potential antagonism between $\mathrm{Co}$ and $\mathrm{Cu}$.

The primary objective of this study was to examine the relative long term interactions between $\mathrm{Co}$ and $\mathrm{Cu}$ in weanling pigs fed high $\mathrm{Cu}$ diets.

\section{MATERIAL AND METHODS}

\section{Animals and diets}

Two similar feeding trials were conducted, using a total of 192 crossbred weanling pigs (equal numbers of gilts and barrows). Pigs were weaned at a mean age of $35 \mathrm{~d}$ and were given a $7-\mathrm{d}$ adjustment period in the nurseries before treatments were started. Pigs were housed in enclosed environmentally regulated rooms in $0.61 \mathrm{~m} \times 0.91 \mathrm{~m}$ pens (two pigs/pen) with plastic-coated welded wire flooring. Recommended ventilation rates (Murphy et al., 1990) and tem- 
peratures (Harp and Huhnke, 1992) were maintained. The care and treatment of pigs followed published guidelines (Consortium, 1988).

A $20 \%$ crude protein maize-soyabean meal-dried whey basal diet (Table 1) was formulated to meet or exceed the National Research Council recommended nutrient requirements (NRC, 1988). Experimental diets were prepared by substituting maize in the basal diet with appropriate levels and copper sulphate or cobalt chloride (Sigma Chemical Co., St. Louis, MO, USA). Pigs were given free access to feed and water during the adjustment and experimental periods.

In experiment 1,96 weanling pigs (mean body weight of $8.2 \mathrm{~kg}$ ) were randomly assigned into six treatments from outcome groups based on weight and gender. Littermates were balanced across treatments as much as possible. A $2 \times 3$ factorial arrangement of treatments was employed using two levels of $\mathrm{Cu}$ ( 15 and $280 \mathrm{mg} / \mathrm{kg})$ and three levels of added Co $(0,150$ and $300 \mathrm{mg} / \mathrm{kg})$.

Blood samples were collected via vena cava puncture at the start and at the end of the experiment. During the 35-d experiment, pigs were weighed and feed intake was recorded every week. At the end of the experiment, 24 pigs (four from each treatment) were randomly chosen and killed by electrocution and exsanguination. Whole brain, liver, and both kidneys were collected and stored at $-20^{\circ} \mathrm{C}$ for later analysis of mineral concentrations.

In experiment 2,96 crossbred pigs (mean BW of $7.2 \mathrm{~kg}$ ) were randomly assigned to the same dietary treatment arrangement as used in experiment 1 . Twenty-four pigs (four pigs per treatment) were killed at $d 14$ and another 24 pigs were killed at $\mathrm{d} 28$. Body weights were taken and blood samples were taken every week. Brain, liver, and kidney were collected and frozen at $-20^{\circ} \mathrm{C}$ for later mineral analysis.

TABLE 1

Composition (as-is basis) of basal diet for adjustment and experimental periods ${ }^{\mathrm{a}}$

\begin{tabular}{lc}
\hline Ingredients & $\mathrm{g} / \mathrm{kg}$ diet \\
\hline Maize & 55.72 \\
Soyabean meal & 32.22 \\
Dricd whey & 10.10 \\
Ground limestone & 0.40 \\
Dicalcium phosphate & 1.11 \\
Trace mineral premix & 0.10 \\
Vitamin premix & \\
Salt & 0.25 \\
\hline
\end{tabular}

${ }^{a}$ calculated to supply $20 \% \mathrm{CP}, 0.80 \% \mathrm{Ca}$, and $0.65 \% \mathrm{P}$

${ }^{\mathrm{b}}$ supplied per kilogram of diet, mg: $\mathrm{Zn}, 150 ; \mathrm{Fe}, 175 ; \mathrm{Mn}, 60 ; \mathrm{Cu}, 17.5$, and I, 2

" supplied per kilogram of diet: retinyl acetate, $1514 \mu \mathrm{g}$; cholecalciferol, $110 \mu \mathrm{g}$; dl- $\alpha$-tocopheryl acetate, $11 \mathrm{mg}$; riboflavin, $4.4 \mathrm{mg}$; d-pantothenic acid, $22 \mathrm{mg}$; niacin, $22 \mathrm{mg}$; choline $489.5 \mathrm{mg}$; cyanocobalamin, $22 \mu \mathrm{g}$; menadione, $0.5 \mathrm{mg}$; d-biotin, $0.44 \mathrm{mg}$ and $\mathrm{Se}, 0.3 \mathrm{mg}$ 


\section{Mineral analysis}

Serum samples were diluted with distilled water and the $\mathrm{Cu}$ concentration was measured using a flame atomic absorption spectrophotometer (Perkin Elmer 5100 , Corwalk, CT, USA). Whole organs were homogenized with an Osterizer blender. Samples of the homogenates were wet digested using nitric acid and perchloric acid (AOAC, 1990). Mineral $(\mathrm{Cu}, \mathrm{Co}, \mathrm{Zn}$ and $\mathrm{Fe}$ ) concentrations were measured by flame atomic absorption spectrophotometry. Certified mineral reference solutions (Fisher Scientific, Fair Lawn, NJ, USA) were used as standards. Dry matter contents of tissue homogenates were also determined (AOAC, 1990). Tissue mineral concentrations are expressed on a dry matter basis.

\section{Statistical analysis}

Data were analyzed using the GLM procedures of SAS (1988). Pen means were treated as experimental units for analyzing performance data, while individual pigs were used as experimental units for analyzing mineral data. The initial model included $\mathrm{Cu}$ level, $\mathrm{Co}$ level, $\mathrm{Cu} \times \mathrm{Co}$ interaction, gender and replicates. Gender effects were not significant and thus subsequently removed from the model. Dose response of pig performance to Co was tested in terms of

TABLE 2

Effect of dietary copper and cobalt on serum copper concentration in weanling pigs

\begin{tabular}{|c|c|c|c|c|c|c|c|}
\hline $\begin{array}{l}\mathrm{Cu}, \mathrm{mg} / \mathrm{kg}^{\mathrm{a}} \\
\mathrm{Co}, \mathrm{mg} / \mathrm{kg}^{\mathrm{a}}\end{array}$ & $\begin{array}{l}15 \\
<2\end{array}$ & $\begin{array}{c}15 \\
150\end{array}$ & $\begin{array}{c}15 \\
300\end{array}$ & $\begin{array}{l}280 \\
<2\end{array}$ & $\begin{array}{l}280 \\
150\end{array}$ & $\begin{array}{l}280 \\
300\end{array}$ & SEM \\
\hline \multicolumn{8}{|c|}{ Experiment $1^{\mathrm{b}}, \mu \mathrm{g} / \mathrm{ml}$} \\
\hline D 0 & 1.62 & 1.63 & 1.61 & 1.65 & 1.63 & 1.69 & 0.052 \\
\hline D $35^{\mathrm{dr}}$ & 1.49 & 1.53 & 1.44 & 1.62 & 1.77 & 1.54 & 0.038 \\
\hline \multicolumn{8}{|c|}{ Experiment $2^{c}, \mu \mathrm{g} / \mathrm{ml}$} \\
\hline D 0 & 1.71 & 1.65 & 1.71 & 1.64 & 1.60 & 1.61 & 0.043 \\
\hline $\mathrm{D} 7^{\mathrm{d}}$ & 1.53 & 1.56 & 1.60 & 1.69 & 1.80 & 1.68 & 0.056 \\
\hline D $14^{\text {der }}$ & 1.37 & 1.37 & 1.37 & $\mathrm{~J} .53$ & 1.76 & 1.49 & 0.052 \\
\hline D $21^{\mathrm{d}}$ & 1.44 & 1.52 & 1.44 & 1.68 & 1.86 & 1.72 & 0.067 \\
\hline D $28^{d}$ & 1.61 & 1.70 & 1.63 & 1.78 & 2.00 & 1.79 & 0.078 \\
\hline
\end{tabular}

\footnotetext{
"upon analysis of feed

beach mean represents 16 pigs

" each mean represents 16 pigs up to $\mathrm{d} 14$. After d 14, each mean represents eight pigs

${ }^{d} \mathrm{Cu}$ effect $(\mathrm{P} \leqslant 0.05)$

${ }^{e} \mathrm{Cu}$ level x Co level interaction $(P \leqslant 0.05)$

${ }^{f}$ quadratic cobalt effect $(P \leqslant 0.05)$
} 
linear and quadratic effects, using orthogonal polynomial tests. Orthogonal polynomial constans were calculated according to Cady and Fuller (1968).

\section{RESULTS}

\section{Serum copper concentration}

Serum $\mathrm{Cu}$ concentration was increased by $\mathrm{Cu}$ feeding in both experiments (Table 2). In experiment 1 , Co influenced the serum $\mathrm{Cu}$ concentration in a quadratic manner $(P \leqslant 0.05)$, i.e. $150 \mathrm{mg} / \mathrm{kg}$ dietary Co elevated $\mathrm{Cu}$ concentration whereas $300 \mathrm{mg} / \mathrm{kg}$ dietary Co decreased $\mathrm{Cu}$ concentration. In experiment 2 , the quadratic Co effect was significant $(P \leqslant 0.05)$ only at $d 14$. The magnitude of this quadratic effect was much greater for pigs fed high $\mathrm{Cu}$ diets during all periods with a $\mathrm{Cu}$ level $\mathrm{x}$ Co level interaction $(\mathrm{P} \leqslant 0.05)$ observed at only $\mathrm{d} 14$ in experiment 2.

\section{Tissue mineral concentrations}

Copper feeding increased $(\mathrm{P} \leqslant 0.05)$ the concentration of $\mathrm{Cu}$ in the brain (Table 3) in experiment 1 (d 35), and in experiment 2 at $d 28(\mathrm{P} \leqslant 0.05)$, but not at

TABLE 3

Effect of dietary copper and cobalt on brain mineral concentration in weanling pigs

\begin{tabular}{|c|c|c|c|c|c|c|c|}
\hline $\begin{array}{l}\mathrm{Cu}, \mathrm{mg} / \mathrm{kg}^{2} \\
\mathrm{Co}, \mathrm{mg} / \mathrm{kg}^{\mathrm{a}}\end{array}$ & $\begin{array}{l}15 \\
<2\end{array}$ & $\begin{array}{c}15 \\
150\end{array}$ & $\begin{array}{c}15 \\
300\end{array}$ & $\begin{array}{l}280 \\
<2\end{array}$ & $\begin{array}{l}280 \\
150\end{array}$ & $\begin{array}{l}280 \\
300\end{array}$ & SEM \\
\hline \multicolumn{8}{|c|}{ Experiment 1 (d 35), $\mu \mathrm{g} / \mathrm{g}$ of DM ${ }^{b}$} \\
\hline $\mathrm{Cu}^{\mathrm{e}}$ & 31 & 32 & 32 & 42 & 42 & 44 & 3 \\
\hline $\mathrm{Zn}$ & 120 & 121 & 118 & 123 & 118 & 120 & 4 \\
\hline $\mathrm{Fe}$ & 58 & 65 & 64 & 66 & 85 & 69 & 9 \\
\hline \multicolumn{8}{|c|}{ Experiment $2(\mathrm{~d} 14), \mu \mathrm{g} / \mathrm{g}$ of DM } \\
\hline $\mathrm{Cu}$ & 21 & 21 & 21 & 21 & 23 & 22 & 1 \\
\hline $\mathrm{Zn}$ & 67 & 66 & 65 & 66 & 67 & 66 & 1 \\
\hline $\mathrm{Fe}$ & 62 & 67 & 63 & 57 & 62 & 58 & 3 \\
\hline \multicolumn{8}{|c|}{ Experiment 2 (d 28), $\mu \mathrm{g} / \mathrm{g}$ of $\mathrm{DM}^{\mathrm{b}}$} \\
\hline $\mathrm{Cu}^{\mathrm{c}}$ & 20 & 21 & 22 & 22 & 25 & 24 & 1 \\
\hline $\mathrm{Zn}$ & 66 & 63 & 64 & 63 & 63 & 64 & 1 \\
\hline $\mathrm{Fe}$ & 71 & 73 & 75 & 63 & 63 & 55 & 6 \\
\hline
\end{tabular}

apon analyses of feed

${ }^{b}$ each mean represents four pigs

${ }^{*} \mathrm{Cu}$ effect $(\mathrm{P} \leqslant 0.05)$ 
d 14. Brain Co concentrations were lower than the detection limit of flame absorption spectrophotometry (approximately $2 \mathrm{mg} / \mathrm{kg}$ ) and were not analyzed. Zinc and $\mathrm{Fe}$ concentrations in the brain were not affected by dietary $\mathrm{Cu}$ levels. Varying the dietary level of $\mathrm{Co}$ did not influence the $\mathrm{Cu}, \mathrm{Zn}$, and $\mathrm{Fe}$ concentration in the brain.

Concentration of $\mathrm{Cu}$ in the liver was increased $(\mathrm{P} \leqslant 0.05)$ by $\mathrm{Cu}$ feeding in both experiments (Table 4). The effect of $\mathrm{Co}$ on $\mathrm{Cu}$ accumulation in the liver was most evident for pigs fed the high $\mathrm{Cu}$ diets. For pigs fed high $\mathrm{Cu}$ diets, Co seemed to affect liver $\mathrm{Cu}$ deposition quadratically $(\mathrm{P} \leqslant 0.05)$ in both experiments; the highest liver concentration of Cu was observed for pigs fed $150 \mathrm{mg} / \mathrm{kg} \mathrm{Co}$. Cobalt concentration in the liver was linearly increased $(P \leqslant 0.05)$ by increasing levels of dietary $\mathrm{Co}$. Copper feeding reduced the accumulation of $\mathrm{Co}$ in the liver of pigs fed $300 \mathrm{mg} / \mathrm{kg}$ of dietary $\mathrm{Co}$, which can be seen from a $\mathrm{Cu}$ effect and a $\mathrm{Cu} \times \mathrm{Co}$ interaction $(P \leqslant 0.05)$ at $\mathrm{d} 35$ of experiment 1 and at $\mathrm{d} 14$ of experiment 2 . No effect of $\mathrm{Cu}$ on $\mathrm{Co}$ deposition was observed at $\mathrm{d} 28$ of experiment 2.

TABLE 4

Effect of dictary copper and cobalt on liver mineral concentration in weanling pigs

\begin{tabular}{|c|c|c|c|c|c|c|c|}
\hline $\begin{array}{l}\mathrm{Cu}, \mathrm{mg} / \mathrm{kg}^{2} \\
\mathrm{Co}, \mathrm{mg} / \mathrm{kg}\end{array}$ & $\begin{array}{l}15 \\
<2\end{array}$ & $\begin{array}{c}15 \\
150\end{array}$ & $\begin{array}{c}15 \\
300\end{array}$ & $\begin{array}{l}280 \\
<2\end{array}$ & $\begin{array}{l}280 \\
150\end{array}$ & $\begin{array}{l}280 \\
300\end{array}$ & SEM \\
\hline \multicolumn{8}{|c|}{ Experiment $1(\mathrm{~d} 35), \mu \mathrm{g} / \mathrm{g}$ of $\mathrm{DM}^{\mathrm{h}}$} \\
\hline $\mathrm{Cu} \bowtie$ & 39 & 37 & 47 & 745 & 1038 & 884 & 116 \\
\hline Co er & $<2$ & 9 & 26 & $<2$ & 10 & 12 & 1 \\
\hline $\mathrm{Zn}^{\mathrm{d}}$ & 231 & 159 & 187 & 252 & 228 & 163 & 20 \\
\hline $\mathrm{Fe}^{\mathrm{c}}$ & 423 & 524 & 573 & 473 & 264 & 228 & 80 \\
\hline \multicolumn{8}{|c|}{ Experiment $2(\mathrm{~d} 14), \mu \mathrm{g} / \mathrm{g}$ of $\mathrm{DM}^{\mathrm{b}}$} \\
\hline $\mathrm{Cu} \times$ & 85 & 83 & 78 & 150 & 264 & 178 & 25 \\
\hline Co ${ }^{\text {dd } f}$ & $<2$ & 11 & 27 & $<2$ & 10 & 12 & 3 \\
\hline $\mathrm{Zn}^{\mathrm{c}}$ & 171 & 169 & 193 & 129 & 151 & 132 & 23 \\
\hline $\mathrm{Fe}^{\mathrm{ce}}$ & 258 & 448 & 230 & 148 & 200 & 183 & 60 \\
\hline \multicolumn{8}{|c|}{ Experiment $2(\mathrm{~d} 28), \mu \mathrm{g} / \mathrm{g}$ of $\mathrm{DM}^{b}$} \\
\hline $\mathrm{Cu}$ & 24 & 28 & 42 & 398 & 806 & 495 & 111 \\
\hline $\mathrm{Co}^{\mathrm{d}}$ & $<2$ & 12 & 19 & $<2$ & 11 & 19 & 4 \\
\hline $\mathrm{Zn}^{\mathrm{d}}$ & 197 & 165 & 130 & 192 & 149 & 140 & 23 \\
\hline $\mathrm{Fe}^{\text {id }}$ & 363 & 394 & 222 & 255 & 128 & 115 & 43 \\
\hline
\end{tabular}

apon analysis of feed

b cach mean represents four pigs

' $\mathrm{Cu}$ effect $(\mathrm{P} \leqslant 0.05)$

${ }^{d}$ Co linear effect $(P \leqslant 0.05)$

- Co quadratic effect $(P \leqslant 0.05)$

${ }^{\prime} \mathrm{Cu} \times \mathrm{Co}$ interaction $(P \leqslant 0.05)$

${ }^{\mathrm{g}} \mathrm{Cu} \times \mathrm{Co}$ interaction $(\mathrm{P} \leqslant 0.10)$ 
Copper feeding reduced $(P \leqslant 0.05)$ liver $Z n$ deposition only at $\mathrm{d} 14$ of experiment 2 . Generally, $\mathrm{Zn}$ concentration in the liver was linearly decreased $(\mathrm{P} \leqslant 0.05)$ by increasing dietary Co levels except for $\mathrm{d} 14$ of experiment 2 . Liver $\mathrm{Fe}$ deposition was reduced $(\mathrm{P} \leqslant 0.05)$ by $\mathrm{Cu}$ feeding in both experiments. The effect of $\mathrm{Co}$ on liver Fe was not consistent. In experiment 1, the effect of dietary Co on Fe concentration in the liver was not significant (d 35); but at d 14 of experiment 2, Co quadratically influenced $\mathrm{Fe}$ concentration with the highest liver $\mathrm{Fe}$ concentration occurring in the $150 \mathrm{mg} / \mathrm{kg}$ Co groups.

Copper feeding increased $(\mathrm{P} \leqslant 0.05)$ kidney $\mathrm{Cu}$ concentrations at $\mathrm{d} 35$ of experiment 1 , but not at d 14 or 28 of experiment 2 (Table 5). In both experiments, kidney $\mathrm{Cu}$ concentrations were reduced linearly $(\mathrm{P} \leqslant 0.05)$ by dietary $\mathrm{Co}$. Cobalt deposition in the kidney was linearly increased by increasing dietary Co level in both experiment $(P \leqslant 0.05)$, but was not influenced by $\mathrm{Cu}$ supplementation. Concentration of $\mathrm{Zn}$ in the kidney was not influenced by dietary $\mathrm{Cu}$ or $\mathrm{Co}$ levels. High dietary $\mathrm{Cu}$ reduced $(\mathrm{P} \leqslant 0.05)$ kidney $\mathrm{Fe}$ concentration only on d 14 of experiment 2 . Cobalt feeding increased $(\mathrm{P} \leqslant 0.05)$ kidney $\mathrm{Fe}$ concentration in experiment 2 but not in experiment 1 .

TABLE 5

Effect of dietary copper and cobalt on kidney mineral concentration in weanling pigs

\begin{tabular}{|c|c|c|c|c|c|c|c|}
\hline $\begin{array}{l}\mathrm{Cu}, \mathrm{mg} / \mathrm{kg}^{\mathrm{a}} \\
\mathrm{Co}, \mathrm{mg} / \mathrm{kg}^{3}\end{array}$ & $\begin{array}{l}15 \\
<2\end{array}$ & $\begin{array}{l}15 \\
150\end{array}$ & $\begin{array}{c}15 \\
300\end{array}$ & $\begin{array}{l}280 \\
<2\end{array}$ & $\begin{array}{l}280 \\
150\end{array}$ & $\begin{array}{l}280 \\
300\end{array}$ & SEM \\
\hline \multicolumn{8}{|c|}{ Experiment $1(\mathrm{~d} 35), \mu \mathrm{g} / \mathrm{g}$ of $\mathrm{DM}^{\mathrm{b}}$} \\
\hline $\mathrm{Cu}$ & 64 & 26 & 25 & 87 & 38 & 34 & 12 \\
\hline $\mathrm{Co}^{\mathrm{d}}$ & $<3$ & 26 & 55 & $<3$ & 35 & 64 & 4 \\
\hline $\mathrm{Zn}$ & 84 & 64 & 64 & 71 & 71 & 58 & 7 \\
\hline $\mathbf{F e}$ & 165 & 200 & 253 & 210 & 184 & 156 & 2 \\
\hline \multicolumn{8}{|c|}{ Experiment 2 (d 14), $\mu \mathrm{g} / \mathrm{g}$ of $\mathrm{DM}^{\mathrm{b}}$} \\
\hline $\mathrm{Cu}^{\mathrm{f}}$ & 40 & 31 & 28 & 34 & 44 & 19 & 25 \\
\hline $\mathrm{Co}^{\mathrm{a}}$ & $<5$ & 29 & 49 & $<5$ & 34 & 49 & 3 \\
\hline $\mathrm{Zn}$ & 105 & 103 & 118 & 93 & 100 & 96 & 23 \\
\hline $\mathrm{Fe}$ ede & 119 & 196 & 181 & 96 & 151 & 150 & 60 \\
\hline \multicolumn{8}{|c|}{ Experiment $2(\mathrm{~d} 28), \mu \mathrm{g} / \mathrm{g}$ of $\mathrm{DM}^{\mathrm{b}}$} \\
\hline $\mathrm{Cu}^{\mathrm{d}}$ & 36 & 40 & 26 & 76 & 28 & 32 & 10 \\
\hline $\mathrm{Co}^{\mathrm{d}}$ & $<5$ & 30 & 58 & $<5$ & 40 & 53 & 6 \\
\hline $\mathrm{Zn}$ & 111 & 118 & 107 & 111 & 99 & 105 & 4 \\
\hline $\mathrm{Fe}^{d}$ & 148 & 177 & 177 & 129 & 111 & 112 & 13 \\
\hline
\end{tabular}

a upon analysis of feed

${ }^{b}$ cach mean represents four pigs

- $\mathrm{Cu}$ effect $(\mathrm{P} \leqslant 0.05)$

${ }^{d}$ Co linear effect $(P \leqslant 0.05)$

- Co quadratic effect $(P \leqslant 0.05)$

'Co linear cflect $(P \leqslant 0.07)$ 


\section{Growth performance}

In experiment 1 , high levels of dietary $\mathrm{Cu}$ stimulated $(\mathrm{P} \leqslant 0.05)$ growth during $\mathrm{d} 1$ to 7 (Table 6). This occurred through an increase $(P \leqslant 0.05)$ in both daily feed intake (ADFI) and gain per feed (GF). No significant $\mathrm{Cu} \times \mathrm{Co}$ interaction in average daily gain (ADG) was found, which indicates that the stimulation of growth was not influenced by $\mathrm{Co}$. During $\mathrm{d} I$ to 7 , Co supplementation linearly decreased $\mathrm{ADG}$ at both $\mathrm{Cu}$ levels $(\mathrm{P} \leqslant 0.05)$. ADFI and GF were not influenced by Co treatments. During $\mathrm{d} 8$ to 28 , no significant effect of dietary treatments was observed, but during $\mathrm{d} 29$ to 35 , both $\mathrm{Co}$ and $\mathrm{Cu}$ decreased growth rate $(\mathrm{P} \leqslant 0.05)$. Overall ( $\mathrm{d} 1$ to 35$)$, the addition of high levels of dietary $\mathrm{Cu}$ did not influence growth performance, whereas dietary Co linearly decreased $(P \leqslant 0.05)$ growth rate, which was a result of numerical reductions in ADFI and GF.

In experiment 2, when Co was not supplemented, $\mathrm{Cu}$ numerically improved ADG and ADFI during $d 1$ to 14, but not during d 15 to 28, when Co was not supplemented (compare data column 1 and 4 in Table 6). Dietary Co linearly decreased $(P \leqslant 0.05)$ ADG and ADFI regardless of dietary $\mathrm{Cu}$ levels. GF was also reduced $(P \leqslant 0.05)$ by Co treatment, which indicates that the reduced growth rate was due to a decreased feed intake and reduced feed efficiency. Copper seems to increase the slope of the linear effect of $\mathrm{Co}$. In other words, $\mathrm{Cu}$ decreased the growth rate by enhancing the growth inhibitory action of $\mathrm{Co}(\mathrm{Cu} \times \mathrm{Co}$ interaction, $\mathbf{P} \leqslant 0.08$ ).

\section{DISCUSSION}

\section{Copper-cobalt interaction and mineral metabolism}

The interaction between $\mathrm{Cu}$ and $\mathrm{Co}$ had not been well studied until recently (Rosenberg and Kappas, 1989a, b). The unique ability of Co to increase $\mathrm{Cu}$ excretion was observed when Rosenberg and Kappas (1989a) were studying the interaction between $\mathrm{Co}$ and a number of metals including $\mathrm{Cu}$. A subcutaneous injection of Co induced a rapid urinary excretion of $\mathrm{Cu}$ in rats (within $24 \mathrm{~h}$ ). A $20 \%$ reduction in the $\mathrm{Cu}$ concentration of the liver was observed $6 \mathrm{~d}$ after $\mathrm{Co}$ injection. Our experiments with pigs, however, suggest that Co feeding does not reduce liver $\mathrm{Cu}$ accumulation even in long term studies. In fact, in our experiments, Co tended to increase liver $\mathrm{Cu}$ deposition, either linearly or quadratically. Cobalt also failed to reduce brain $\mathrm{Cu}$ deposition.

Rosenberg and Kappas (1989b) observed that $\mathrm{Cu}$ deposition in the kidney was reduced approximately $30 \%$ three days after an injection of Co. In our experiments, Co feeding also resulted in a large reduction in kidney $\mathrm{Cu}$ 
TABLE 6

Effect of dietary copper and cobalt on growth performance in weanling pigs ${ }^{a}$

\begin{tabular}{|c|c|c|c|c|c|c|c|}
\hline $\begin{array}{l}\mathrm{Cu}, \mathrm{mg} / \mathrm{kg}^{\mathrm{a}} \\
\mathrm{Co}, \mathrm{mg} / \mathrm{kg}^{\text {a }}\end{array}$ & $\begin{array}{l}15 \\
<2\end{array}$ & $\begin{array}{c}15 \\
150\end{array}$ & $\begin{array}{c}15 \\
300\end{array}$ & $\begin{array}{l}280 \\
<2\end{array}$ & $\begin{array}{l}280 \\
150\end{array}$ & $\begin{array}{l}280 \\
300\end{array}$ & SEM \\
\hline \multicolumn{8}{|c|}{ Experiment $1^{\mathrm{c}}$} \\
\hline \multicolumn{8}{|l|}{ D $1-7$} \\
\hline ADG, $g^{\text {de }}$ & 273 & 221 & 207 & 318 & 325 & 288 & 17 \\
\hline ADFI, $g{ }^{d}$ & 417 & 371 & 398 & 468 & 472 & 418 & 19 \\
\hline $\mathrm{GF}, \mathrm{g} / \mathrm{kg}^{\mathrm{d}}$ & 660 & 594 & 524 & 679 & 686 & 693 & 45 \\
\hline \multicolumn{8}{|l|}{ D $8-28$} \\
\hline $\mathrm{ADG}, \mathrm{g}$ & 445 & 449 & 400 & 508 & 484 & 420 & 25 \\
\hline $\mathrm{ADFI}, \mathrm{g}$ & 842 & 823 & 756 & 835 & 886 & 791 & 42 \\
\hline $\mathrm{GF}, \mathrm{g} / \mathrm{kg}$ & 529 & 495 & 559 & 534 & 549 & 538 & 20 \\
\hline \multicolumn{8}{|l|}{ D $29-35$} \\
\hline ADG, $g{ }^{\text {def }}$ & 615 & 575 & 510 & 520 & 565 & 358 & 30 \\
\hline ADFI, $\mathrm{g}$ & 1251 & 1239 & 1165 & 1170 & 1189 & 1025 & 54 \\
\hline $\mathrm{GF}, \mathrm{g} / \mathrm{kg}$ & 491 & 475 & 441 & 452 & 478 & 354 & 33 \\
\hline \multicolumn{8}{|l|}{ D $1-35$} \\
\hline $\mathrm{ADG}, \mathrm{g}^{\mathrm{e}}$ & 439 & 394 & 392 & 435 & 466 & 382 & 21 \\
\hline ADFI, $\mathbf{g}$ & 826 & 804 & 754 & 818 & 855 & 755 & 32 \\
\hline \multirow[t]{2}{*}{$\mathrm{GF}, \mathrm{g} / \mathrm{kg}$} & 532 & 498 & 524 & 532 & 547 & 505 & 15 \\
\hline & \multicolumn{7}{|c|}{ Experiment $2^{\mathrm{c}}$} \\
\hline \multicolumn{8}{|l|}{ D $1-14 b$} \\
\hline $\mathrm{ADG}, \mathrm{g}$ & 259 & 197 & 158 & 304 & 187 & 109 & 32 \\
\hline ADFI, $g^{c}$ & 459 & 383 & 325 & 525 & 373 & 306 & 32 \\
\hline GF, $\mathrm{g} / \mathrm{kg}^{\mathrm{e}}$ & 579 & 509 & 494 & 561 & 473 & 327 & 46 \\
\hline \multicolumn{8}{|l|}{ ED $15-28 \mathrm{c}$} \\
\hline ADG, $g^{\mathrm{efg}}$ & 598 & 458 & 397 & 600 & 248 & 172 & 52 \\
\hline ADFI, $g^{\text {de }}$ & 1037 & 866 & 731 & 1040 & 593 & 489 & 81 \\
\hline $\mathrm{GF}, \mathrm{g} / \mathrm{kg}$ def & 579 & 542 & 544 & 586 & 403 & 275 & 53 \\
\hline
\end{tabular}

aDG = average daily gain, ADFI = average daily feed intake and GF = gain per feed

${ }^{b}$ upon analyses of feed

' each mean represents eight pens with two pigs per pen in experiment 1 and cach mean represents eight pens with two pigs per pen to $d 14$, then there were four pens with one pig per pen and four pens with two pigs per pen in experiment 2

${ }^{d} \mathrm{Cu}$ effect $(P \leqslant 0.05)$

' $C o$ linear effect $(P \leqslant 0.05)$

${ }^{f}$ Co quadratic effect $(P \leqslant 0.05)$

${ }^{2} \mathrm{Cu}$ x Co interaction $(\mathrm{P} \leqslant 0.08)$ 
concentration (approximately $50 \%$ in pigs fed $280 \mathrm{mg} / \mathrm{kg}$ dietary $\mathrm{Cu}$ ), which confirnred a tissue specific $\mathrm{Cu} \times \mathrm{Co}$ antagonism in pigs.

Excessive liver and brain $\mathrm{Cu}$ depositions are involved in the pathogenesis of Wilson's disease (Owen, 1981; Wilson, 1982). Inorganic Co was being evaluated as an agent for treating Wilson's desease (Rosenberg and Kappas, 1989b). The failure of $\mathrm{Co}$ in pigs to reduce liver or brain $\mathrm{Cu}$ deposition raises a doubt about the therapeutic value of inorganic $\mathrm{Co}$, unless humans react differently from pigs. Nevertheless, the unique organ and species specific interaction between $\mathrm{Cu}$ and Co is rather interesting.

The major effect of the high level of $\mathrm{Cu}$ on liver Co deposition appears to be the prevention of the accumulation of Co when pigs were fed the highest level of dietary $\mathrm{Co}(300 \mathrm{mg} / \mathrm{kg})$. Because only two levels of dietary $\mathrm{Cu}$ were used in our experiments, it is difficult to draw a clear conclusion on the nature of this interaction. Some other minerals are also possibly antagonistic to Co. Iron has been reported to reduce Co absorption in rats (Thomson et al., 1971a,b). A combination of high dietary $\mathrm{Fe}, \mathrm{Mn}$, and $\mathrm{Zn}$ reduced Co deposition in kidney and liver and alleviated Co toxicity in pigs (Huck and Clawson, 1976). However, the effect of individual minerals on tissue Co in pigs was not studied in that experiment.

Rosenberg and Kappas (1989b) found that Co injection produced a dose dependent elevation of liver $\mathrm{Zn}$ in rats. This increase was due to the synthesis of liver metallothionein which binds $\mathrm{Zn}$ and increases liver $\mathrm{Zn}$ concentration. However, our results show that a high dietary level of Co either had no effect on, or reduced liver $\mathrm{Zn}$ levels in pigs. This discrepancy might be due to different routes of administration, i.e., oral administration vs. subcutaneous injections. One important site where mineral antagonism occurs is in intestinal absorption (Wapnir, 1990). It is speculated that dietary Co may interfere with $\mathrm{Zn}$ absorption. Even though liver metallothionein synthesis might be induced by $\mathrm{Co}$ feeding, $\mathrm{Zn}$ storage would still be depleted because of a lower absorption rate or supply of $\mathrm{Zn}$. This is analogous to the $\mathrm{Cu} \times \mathrm{Zn}$ antagonism where $\mathrm{Cu}$ feeding reduced liver $\mathrm{Zn}$ levels (Hedges and Kornegay, 1973); while $\mathrm{Cu}$ injection increased liver Zn storage (Zhou et al., 1994).

The effect of Co on liver Fe storage was studied by Huck and Clawson (1976) who found that dietary supplementation of Co significantly reduced Fe storage in pigs. Our results generally support this conclusion.

\section{Growth performance}

Statistically significant $\mathrm{Cu}$-stimulated growth was only seen in the first week of experiment 1. In experiment 2, when the two groups receiving no Co supplementation were compared, the high $\mathrm{Cu}$ group had numerically improved 
performance compared with the low $\mathrm{Cu}$ group during the first $14 \mathrm{~d}$. Copper-stimulated growth disappeared in the following weeks. The short term growth stimulation was probably due to an excessive level of dietary $\mathrm{Cu}$. Because diets containing $280 \mathrm{mg} / \mathrm{kg}$ of $\mathrm{Cu}$ (upon analysis of feed) were used rather than $250 \mathrm{mg} / \mathrm{kg}$ commonly used in swine production, it was possible that pigs accumulated too much $\mathrm{Cu}$ and marginal $\mathrm{Cu}$ toxicity might have developed after the first week. Similarly, Kornegay et al. (1989) found that $400 \mathrm{mg} / \mathrm{kg}$ of dietary $\mathrm{Cu}$ stimulated the growth of pigs in the first week and the growth stimulation disappeared in the subsequent weeks, presumably because of $\mathrm{Cu}$ toxicity.

The growth retardation in pigs by high levels of Co was due to a combination of a decline in feed consumption and feed efficiency, which is consistent with findings of Huck and Clawson (1976). In the study of Huck and Clawson (1976), $200 \mathrm{mg} / \mathrm{kg}$ of dietary Co was found to have no detrimental effect on pigs. Based on their report, NRC (1980) recommended $200 \mathrm{mg} / \mathrm{kg}$ as the tolerance level of dietary Co for pigs. In contrast, our results showed that $150 \mathrm{mg} / \mathrm{kg}$ of Co significantly reduced growth rate, suggesting that tolerance level may be lower than $150 \mathrm{mg} / \mathrm{kg}$ for weanling pigs.

Growth performance data from our two experiments were not conclusive on the nature of the interactions between $\mathrm{Cu}$ and $\mathrm{Co}$. In experiment 1 , the $\mathrm{Cu} \times \mathrm{Co}$ interaction was not significant. In experiment 2, Co linearly depressed ADG of pigs fed both levels of $\mathrm{Cu}$; however, the slope of this linear depression was much greater for pigs fed the high level of $\mathrm{Cu}$. It seems that $\mathrm{Cu}$ aggravated the growth depression by Co. This difference may be due to a variable response of pigs to Co. More animals are needed to define clearly the growth response to $\mathrm{Cu}$ and $\mathrm{Co}$ supplementation.

\section{CONCLUSION}

Contrary to previous reports with rats, Co seemed to be ineffective for preventing brain and liver $\mathrm{Cu}$ deposition for pigs. The therapeutic value of $\mathrm{Co}$ for treating Wilson's disease in humans needs to be further evaluated. In addition, our data suggest that the maximal Co tolerance level for weanling pigs (approximately $8 \mathrm{~kg} \mathrm{BW}$ ) should be lower than $150 \mathrm{mg} / \mathrm{kg}$ diet.

\section{ACKNOWLEDGEMENT}

The research was supported by the John Lee Pratt Animal Nutrition Program. This material is based on work supported in part by the Cooperative State Research Service, USDA, under project no. 6129880. 


\section{REFERENCES}

AOAC, 1990. Official Methods of Analysis. 15th ed. Association of Official Analytical Chemists, Arlington, VA

Bowland J.P., 1991. Copper as a performance promoter for pigs. Pig News Inform. 11, 163-167

Cady F.B., Fuller W.A., 1968. Use of regression residuals in the calculation of orthogonal cocfficients. Agron. J. 60, 195-197

Consortium, 1988. Guide for the Care and Use of Agricultural Animals in Agricultural Research and Teaching. Consortium for Developing a Guide for the Care and Use of Agricultural Animals in Agricultural Research and Teaching. Champaign, Il

Cromwell G.L.. Hays V.W., Cark T.L., 1978. Effects of copper sulfate, copper sulfide and sodium sulfide on performance and copper stores of pigs. J. Anim. Sci. 46, 692-698

Cromwell G.L., Stahly T.S., Monegue H.J., 1989. Effects of level and source of copper on performance and liver copper levels of weanling pigs. J. Anim. Sci. 67, 2996-3002

Ewan R., 1986. Analysis of feed and feed ingredients. lowa State University, Swine Research Report 1986, pp. 57

Harp S.L., Huhnke R.L., 1992. Supplemental heat for swine. In: Pork Industry Handbook, \#57. Purdue University, West Lafayette, IN

Hedges J.D., Kornegay E.T., 1973. Interrelationship of dietary copper and iron as measured by blood parameters, tissue stores and feedlot performance of swine. J. Anim. Sci. 37, 1147-1154

Huck D.W., Clawson A.J., 1976. Excess dietary cobalt in pigs. J. Anim. Sci. 43, 1231-1246

Kornegay E.T., van Heugten P.H.G., Lindemann M.D., Blodgett D.J., 1989. Effects of biotin and high copper levels on performance and immune response of weanling pigs. J. Anim. Sci. 67, 1471-1477

Murphy J.P., Jones D.D., Christianson L.L., 1990. Mechanical ventilation of swine buildings. In: Pork Industry Handbook, \#60. Purdue University, West Lafayette, IN

NRC, 1980. Mineral Tolerance of Domestic Animals. National Academy of Sciences, Washington, D.C. pp. 154-161

NRC, 1988. Nutrient Requirements of Swine. 9th edition, Washington, D.C.

Owen C.A., 1981. Wilson's Disease, The Etiology, Clinical Aspects and Treatment of Inherited Cu Toxicity. Noyes Publications, Park Ridge, NJ, pp. 1-215

Prince T.J., Hays V.W., Cromwell G.L., 1979. Effects of copper sulfate and ferrous sulfide on performance and liver copper and iron stores of pigs. J. Anim. Sci. 49, 507-513

Ridberiro de Lima F., Stahly T.S., Cromwell G.L., 1981. Effects of copper, with and without ferrous sulfide, and antibiotics on the performance of pigs. J. Anim. Sci. 52, 241-247

Rosenberg D.W., Kappas A., 1989a. The comparative ability of exogenously administered metals to alter tissue levels and urinary output of copper and zinc. Pharmacology 38, 159-166

Rosenberg D.W., Kappas A., 1989b. Trace metal interactions in vivo, inorganic cobalt enhances urinary copper excretion without producing an associated zincuresis in rats. J. Nutr. 119, 1259-1268

SAS, 1988. SAS/STAT. SAS Inst. Inc. Cary, NC

Thomson A.B.R., Shaver C., Lee D.J., Jones B.L., Valberg L.S., 1971a. Effect of varying iron stores on the site of intestinal absorption of cobalt and iron. Amer. J. Physiol. 220, 674-678

Thomson A.B.R., Valberg L.S., Sinclair D.C., 1971b. Competitive nature of the intestinal transport mechanism for cobalt and iron in the rat. J. Clin. Invest. 50, 2384-2394

Underwood E.J., 1971. Trace Elements in Human and Animal Nutrition. 3rd edition, Academic Press, New York, NY

Walshe J.M., 1956. Penicillinaminc, a new oral therapy for Wilson's diseasc. Amer. J. Med. 21, 487-495 
Wapnir R.A., 1990. Protein Nutrition and Mineral Absorption. CRC Press, Boston, MA, pp. 43-5 Wilson S.A.K., 1982. Progressive lenticular degeneration, A familial nervous discase associated with cirrhosis of the liver. Brain 34, 295-309

Zhou W., Kornegay E.T., Lindemann M.D., Swinkels J.W.G.M., Welten M.K., Wong E.A., 1994. Stimulation of growth by intravenous injection of copper in weanling pigs. J. Anim. Sci. 72, 2395-2403

\section{STRESZCZENIE}

Antagonizm kobalt - miedź w badaniach nad stymulowanym miedzią wzrostem odsadzonych prosiąt

Przeprowadzono 2 doświadczenia na 96 mieszańcach, każde dla zbadania wpływu działania Co na obniżenie gromadzenia $\mathrm{Cu}$ w tkankach świń. W obydwóch doświadczeniach zastosowano układ czynnikowy 2 x $3, z$ dwoma poziomami Cu $(15 i 280 \mathrm{mg} / \mathrm{kg})$ i trzema poziomami dodanego $\mathrm{Co}(0,150$ i $300 \mathrm{mg} / \mathrm{kg}$ ). Początkowa masa ciała prosiąt wynosiła $8,2 \mathrm{~kg} \mathrm{w}$ doświadczeniu 1 i $7,2 \mathrm{~kg}$ w doświadczeniu 2. Próby tkanek do oznaczania skladników mineralnych pobierano 35 dnia w doświadczeniu 1 oraz 14 i 28 dnia w doświadczeniu 2 . Kobalt nie zmnicjszal odkladania Cu w wątrobie i mózgu przy obydwóch poziomach $\mathrm{Cu}$, lecz zwiększal $(\mathbf{P} \leqslant 0.05)$ odkładanic $\mathrm{Cu}$ w wątrobie przy najwyższej dawce $\mathrm{Co}-150 \mathrm{mg} / \mathrm{kg}$. Zwiększenie natomiast dawki Co liniowo obniżało $(P \leqslant 0.05)$ odkładanie $C u$ w nerkach i $Z n$ w wątrobie. Wysoka dzienna dawka $C u$ zwiększała $(\mathrm{P} \leqslant 0.05)$ koncentrację $\mathrm{Cu}$ w osoczu i odkładanie $\mathrm{Cu} w$ wątrobie, mózgu i nerkach. Podawanic $\mathrm{Cu}$ stymulowało $(\mathrm{P} \leqslant 0.05)$ wzrost tylko w ciągu pierwszego tygodnia $w$ doświadczeniu 1 . Uzupełnienie dawki kobaltem - 150 i $300 \mathrm{mg} / \mathrm{kg}$ - znacznie obniżało $(\mathrm{P} \leqslant 0.05)$ pobieranie paszy i tempo wzrostu $(\mathrm{P} \leqslant 0.05)$.

Podsumowując, antagonizm $\mathrm{Cu}-\mathrm{Co}$ jest specyficzny dla poszczególnych rodzajów tkanek i nic może być wykorzystywany do zapobiegania gromadzeniu się $\mathrm{Cu}$ w wątrobie i mózgu. W dodatku tolerancja odsadzonych prosiąt na Co jest niższa niż $150 \mathrm{mg} / \mathrm{kg}$ skarmianych pasz. 